\title{
Animal Rights -'One-of-Us-ness': From the Greek Philosophy towards a Modern Stance
}

\section{Chakraborty S*}

Department of Philosophy, Jadavpur University, India

*Corresponding author: Sanjit Chakraborty, Department of Philosophy, Jadavpur University, India, Tel: 7407916085; Email: cogitosanjit@gmail.com

\section{Research article \\ Volume 1 Issue 1}

Received Date: September 03, 2018

Published Date: September 20, 2018

DOI: $10.23880 /$ phij-16000107

\begin{abstract}
Animals, the beautiful creatures of God in the Stoic and especially in Porphyry's sense, need to be treated as rational. We know that the Stoics ask for justice to all rational beings, but I think there is no significant proclamation from their side that openly talks in favour of animal's justice. They claim about the rationality of animals but do not confer any right to human beings. The later Neo-Platonist philosopher Porphyry magnificently deciphers this idea in his writing On Abstinence from Animal Food. Aristotle's successor Theophrastus thinks that both animals and humans are made up of same tissues and like human, animals also has the same way of perception, reasoning and appetites.

My next effort would be to decipher how Porphyry illustrates Theophrastus' perspective not in the way (the technical theory of justice) the Stoics argued. Porphyry's stance seems more humanistic that looks for the pertinent reasons for treating animal rights from the contention of justice that Aristotle in his early writings defied since the animals can deal with reasons. The paper highlights on how much we could justificatorily demand the empathetic concern for animals from the outlook of the mentioned Greek thinkers and the modern animal rights thinkers as quasi-right of animals, even if my own position undertakes the empathetic ground for animals as an undeserving humanitarian way.
\end{abstract}

Keywords: Animal rights; Porphyry; Singer; Anti-speciesist argument; One-of-us-ness; Empathy

\section{Introduction}

The world is as much as our; in the same way for the animals or non-humans. Non-humans are a bigger part of the world who with us in their regions. They are doubtlessly intelligent, sensitive, emotional and conscious animals. Few decades back, humans basically undermine animals by accusing that animals have no conception regarding responsibility, reason and justice, so we should not be concerned about the right of animals. We can be rationally sympathetic or harmful to animals. The lives of animals are just bow out for the sake of human's needs and feeds. Even in The Vedas, the oldest sacred religious book of the Hindus, animals are viewed as objects that humans can sacrifice to Gods for fulfilling his/her material and intellectual desires like long life, wealth, and salvation. However the Post-Vedic literatures put emphasis on a different view by pondering animals as a part of our life and world. I would not like to stress on these challenging areas as my focus is mainly intense on the Greek Philosophy and its consequences in the modern era.

\section{For Whom We Should be Concerned}

An old debate that always welcomes troubled situations in philosophical analysis is nothing but the moral question of rights to animals or in short, how can 
individual ought to treat the animals accordingly. Ancient Greek philosophy like other philosophical schools, seeks a comprehend moral agency. Humans are doubtlessly moral agents who have reason, responsibility and the power of judgment. But what will be for our fellow non-human animals? Do animals hold any moral agency? If yes, Shall we have moral concern for non-human animals?

Asking about one's own right obviously sounds a type of capability to be rational, moral and responsible agency. Animals do not possess these mentioned humanitarian criterions; therefore like other more affluent civilizations in the ancient periods of Greek (from the pre-Socrates to Plato's periods) and their philosophical expeditions never bestow any kind of concentration on animal rights. I include here Plato on the basis of his loath approach against animals' rights and welfare, whereas the preSocratic thinker Pythagoras (570-495 BCE) had a humanistic compassion about the animals and he is probably the first thinker of the ancient Greek philosophy who wonderfully claims for the safety of non-humans animals and puts it in a way 'As long as man continues to be the ruthless destroyer of lower living beings he will never know health or peace. For as long as men massacre animals, they will kill each other. Indeed, he who sows the seed of murder and pain cannot reap joy and love.' Because Pythagoras believes that the souls of animals and humans are not secluded in nature as both the souls (animals and humans) come from the one origin whom we called God. The problem elevates when both the Stoics and the Aristotelian fail to acknowledge the conceptions of the reasonability and rationality of animals. The Stoic schools provoke justice of all rational beings (the rational beings must have some fellow feelings) but refrained from admitting animal rights as they are neither apprehending on rationality nor on the responsibility. In this point Plato, who believes animals as a reincarnation of human souls further denies the conceptions of reason and rationality from the levels of animals. Plato thinks that animals have intellect, but it is not guided by reason ${ }^{1}$ [1]. However, in Timaeus ${ }^{2}$, Plato also claims positively about the belief procedures of animals that are not available in any plant. Plato seems never talked about the rights of animals [2].

The process of eliminating rationality cum responsibility from animals centres round the Aristotle's stance to look back to the same challenge whether animals have any reason and belief. Unlike his mentor Plato, Aristotle believes in any kind of idealism and lay off

1Plato, Laws, 1921. 961D or 963E.

2Plato, Timaeus, 2008. 77A-C. the conception of provoking on animals' beliefs. Aristotle strongly opposes any type of reason, reasoning, beliefs, thoughts and intellect (nous) in animals mind. As reason is being deficient in animals, so there is no question about the true and false beliefs of animals. Though there may be some animals whom we can teach as they have the capabilities to receive prhonesis extravagances and experience. But they never comprehend about the logical and scientific indulgences.

Aristotle argues:

Next there would be a life of perception, but it also seems to be shared even by the horse, the ox, and every animals. There remains, then, an active life of the element that has reason; of this, one part has it in the sense of being obedient to reason, the other in the sense of possessing reason and exercising thought ${ }^{3}[3]$.

The first reasonable objection is raised by the Stoics and furthermore by Aristotle together against the perceptual content of animals. The Stoics dexterously confine the understanding of perceptual content in the case of humans as their perceptual appearances have some propositional contents. The Stoics put emphasis on the propositional appearances in the animals' sense that either can be verbalised or conceptualised. Animals may have the ability to follow some signs and non-verbal commands, but they are inept to grasp any kind of verbal conditional statements. Long clarifies:

Stoics say that man differs from the irrational animals not in uttered discourse (logos), for crows, parrots and jays utter articulate sounds. Nor does he differ from the other creatures in virtue of impressions created by inference and combination. This amounts to man's possessing an idea of 'connexion' and he grasps the concept of signal because of this ${ }^{4}$ [4].

The Stoics' denial of animals' reason blends with the instruction basing on some sort of impulses. Animals seldom insist on the commands or the instructions of human beings, because of their sensation and life that seem not to be guided by reasons and responsibilities. For the Stoics, our believes are engaged always with assents. Animals don't have the power of assent as they never have the capability to construct belief statements. There are a few who hesitate to admit the experience-based learning of animals, whereas some of the Stoics admit this process. Aristotle takes a steeper appeal when he says animals may have the perceptual appearance but that does not hold any kind of belief. Belief is a procedure

${ }^{3}$ Aristotle, The Nicomachean Ethics, 2009. 1.7, 1098a, 11.

${ }^{4}$ Long A A, 1986, 125. 


\section{Philosophy International Journal}

interlinked to the persuaded and processing reasons; whereas, the neo-Platonists hint towards the rationality. We find an embryonic passage (de Anima) in Aristotle's writing that strongly refuses animals possession of belief and reason. Aristotle argues,

It remains then to see if [appearance (phantasia)] is belief (doxa), for belief comes both true and false. But belief involves conviction (pistis), since in believing one cannot fail to be convinced (pisteuein) by what one believes, whereas conviction is found in no beasts (theria), appearance in many. Furthermore, all belief involves conviction, conviction involves having been persuaded (pepeisthai) and persuasion (peitho) involves reason (logos). Yet whereas appearance is found in some beasts, reason is not ${ }^{5}$ [5].

Now, one can enquire whether we can question the voluntary movement of animals. In his well-known book On The Soul, Aristotle talks about the appearance cum thoughts of the animals together. But for Aristotle, animals' appearances have no conceptualised issue, and their thought refers to the post-perceptual appearances that are unrelated to the belief system. Aristotle who believes in the natural hierarchy of living beings aims to reject the preference of the moral quality in animals. The animals are less reasoning being who only exist for the sake of human beings. The intelligence that animals hold is a kind of simple intelligence guided by emotions which has no relation to the human intelligence nourished by the technical knowledge (tekhne), reason and understanding (sunesis) and so on. In his book On the Soul, Aristotle stresses on the question of proposition and links it to perception. Humans have the perceptual or postperceptual perception (like dream, memory, etc) cum appearances, whereas animals (not all) perceptual appearance cannot able to capture post-perceptual appearances and side by side the propositional structure of beliefs. The animal can see something and feel the conceptions of pleasant or unpleasant, but all these are discarded by any kind of privileged reason. The argument that Aristotle values here is nothing but the perceptual apparatus of animals which have been constructed without any belief. Denial of animals' beliefs sustains from a few ground levels queries like:

a) No animal can set aside the perceived colour red from the propositional belief like 'This is red and it disengages from yellow'.

b) Mere perceptual appearance cannot seize the position of beliefs. Both human and animals perceive sun and

5I quoted the line from Richard Sorabji's work Animals Mind and Humans Morals, 1993. 37. moon as small, but in reality they are not like our perceptual appearance. We can be aware of the truth, but animals cannot know the fact.

c) Animals do not have any belief or degree of beliefs as they cannot convince nor unconvinced others. This is a kind of rhetorical criticism against the belief of animals.

d) The conception of self-persuasion would have definitely lacked in animals minds. Richard Sorabji writes:

The denial that what animals' have is beliefs are not a mere piece of verbal legislation. In the absence of conviction and self-persuasion, Aristotle would think we were wrong to describe their state as belief6.

Here the primordial question is for whom we need to be concerned. Can we concern and be responsible for the non-rational, reasonless, self-persuasion less, belief-less animals who are guided only by perception, voluntary act and emotion? An important point that asks for more clarification is nothing but the conception of the voluntary acts of animals. Aristotle admits the conception although he strongly believes that the voluntary act links to the realm of liability. The origin of the voluntary actions has some internal based roots that in the case of animal are not directed by responsibility and reason. The requirement for any voluntary action is the elements of responsibility, reason and knowledge (it may be true or false), but animals voluntary actions envisage none of the mentioned elements. Animals voluntary acts as a nonrational and non-reason based capacities neither goes beyond reverse outcomes nor to deliberate choices on which Aristotle stressed. Sorabji clarifies Aristotle's position to say:

Non-rational capacities are incapable of opposite outcomes, Aristotle says, whereas rational capacities such as the doctor's ability to heal can be used in opposite ways, either to restore to withhold health. This might have encouraged Aristotle to conclude that only those actions are up to us which are exercises of a rational capacity like medicine, because only those capacities are capacities for opposite outcomes...Deliberate choice comes in at two points, both in the selection of policies to secure goals and in the selection of goals as entering into the ideal life. The deliberate choice of human is carefully distinguished from the merely voluntary acts of animals ${ }^{7}$.

Animals nonetheless even concern about values. They are totally ignorant about the processing of right and

6ibid., 37

7ibid., 109. 
wrong or what we may call 'conscience'. Since the animals voluntary actions are beyond any deliberate choice or reason based outcomes, so here the question of responsibility from human's stance is a prerequisite.

\section{Sense of Justice Versus Justice/Rights Proclaim}

On the basis of 'sense of justice' the concept of animal rights in regard to deserving justice becomes episodic in the Stoics and Aristotle's thoughts as animals don't have any sense of justice since they are the speechless nonrational creatures who are afar from any rational choice stirred by reasons. This outline goes towards a striking consequence, whether animals at all have any right or the sense of justice in general. The Stoics believe in the natural law and instigate on the belief that there is a single and eternal natural law harmonized in nature and Cicero $^{8}$, a leading Stoic emphasised this opinion clearly without giving any attention to animal rights [6]. Aristotle who holds Empedocles' law as natural clarifies that Empedocles takes a stand against animals killing in his universal law $^{9}$ (nomimon). Aristotle allows 'animals' killing' 10 as a right for the purpose of human's ravenous to be fed $[7,8]$. So the Greek philosophers have the idea of right, but they give less importance to animals' right as animals have no sense of justice or demand for justice at all. They endorse the policy that humans can kill animals for their lives, survival and starvation. The domination power or the autocracy of men over the world is god gifted as men are the images of god.

But the proclamation of animal rights in Neo-Platonist Stoic thinker Porphyry's (A.D. 234-to about 305) sense was stimulated by Theophrastus, the successor of Aristotle who considers that animals have the same tissues like humans and their appetites, and reasoning are quite similar to human beings. Stoics' theory of justice impounds themselves just in the mere boundary of human species whereas Theophrastus position gives more concern about the 'justice and right of animals' 11 as he believes that animals hold rationality and reason concurrently [9]. Porphyry, the legendary opponent of

${ }^{8}$ Cicero, On the Republic, 1928. 3.33.

${ }^{9}$ Aristotle writes, 'And so Empedocles, when he bids us kill no living creature, says that doing this is not just for some people while unjust for others', Aristotle, Rhetoric, 2010. 58.

${ }^{10}$ Aristotle says, '... Just as we would not to hunt mankind, whether for food and sacrifice, but only the animals which may be hunted for food or sacrifice, this is to say, such wild animals are eatable.', see Aristotle, Politics, 1999.156.

${ }^{11}$ Theophrastus of Eresus, 1992. 407-37. animals killing in his great treatise On Abstinence from Animal Food was highly motivated by Theophrastus' outlook by becoming a campaigner vegetarian on both devout and moral levels. Porphyry believes in rationality and sentiment of animals and consequently cedes to accept his mentor Aristotle's standpoint against reason and rationality based animated animals. Porphyry says:

But with respect to other animals who do not at all act unjustly, and are not naturally impelled to injure us, it is certainly unjust to destroy and murder them, no otherwise than it would be to slay men who are not iniquitous. And this seems to evince that the justice between us and other animals does not arise from some of them being naturally noxious and malefic, but others not, as is also the case with respect to $\operatorname{men}^{12}[10]$.

Porphyry plunges over an anti-Christian view to prevent animal killing. He castigates the concept of spiritual sacrifice of animals (see, 2.61) and says:

To the gods the best first offering (aparkhê) is a pure intellect and an untroubled soul.

This philanthropic attitude of Porphyry towards animals hinges not only on the abstinence of animals killing simply because of making pleasure and gluttony, but also concerns the natural laws that persist the natural equilibrium between animals and humans. Predecessor Epicurean model propose the killing of animals as humans cannot strike up a peaceful treaty with the animals, and so the only alteration is just to kill them for the sake of human beings. Even the process of killing animals for human's security and gluttony is directed by the first law makers of our society who were more concerned about the advantage of human lives rather than animals. Porphyry discards this type of opinion and infers it as a 'most profound stupidity' of humanity. Porphyry's argument sounds more appealing, when he urges:

It is not necessary; however, that these institutes [of laws] should be preserved by us, because we do not dwell in the same place as those did by whom they were made ${ }^{13}$.

However, in support of veganism, Porphyry illustrates that since the beginning of our primitive age to till now we remain engrossed thinking about what would be the garments of our bodies, but we never thought what would be the best garment for our mind. If flesh is the garment

\footnotetext{
12Porphyry, Selected Works of Porphyry, 1823. 60.

13ibid., 10.
} 


\section{Philosophy International Journal}

of body then thinking is the best garment of mind. But the problem is that the garment of the mind becomes malicious because of the false ideas that only impound us with greed and tyranny that eliminate us from the intertwined parts of animals and the environment. This is really an intellectual crisis of human minds. Successful intellectuals (must be a vegan) are always intended to clean themselves from the inward side. The proper love of true beings ensue in respect to abstaining sensible passions of mind from the pleasure of taking animals fleshes or adopting the brutal ways of killing animals etc. Porphyry suggests human beings to return to their native self where our peaceful mind and body was habituated in taking some vegan products instead of animals' fleshes. Besides, basing on reason (not guided by sensible passions) human beings absorb themselves to the intellectual quests for the goodness of all. Here Porphyry seems more close to Pythagoras, who once taught us that during the golden-age, people 'did not defile their lips with blood'. Even for the case of sacrificing to gods, Pythagoras and his followers never used any kind of animal products; rather they worshiped with wooden products. According to Plato:

...Pythagoras taught 'a way of life,' and we can now see what the purpose of that life was. It was to live in accordance with what is highest in us, remembering always its divine origin ${ }^{14}$ [11].

\section{Relooking the Ideology in Modern Sense}

The ideology of animal rights has two different routesempathy and deontology. Some philosophers think that the non-human animals have moral standing, so we need to be morally apprehensive about their good and welfare. And this is called a moral duty of humanity to the nonhuman animals from our human-side. Other philanthropic philosophers stress their empathies and loves to animals by believing that those animals are the best friend of human or a kind of our relatives with whom we have a kin relationship, also believe in the moral rights of animals as the Stoics hold (especially Porphyry) . Here my attempt is to justify that animal rights do not rely on any human kindness or empathy, but it is really a right that can speak for itself. In the beginning of the paper, I bore in mind that the world is as much as our, in the same status it is also for the non-human animals who have thought, life, intelligence, emotion and rationality like humans. Although the present scenario of the world (environmental misbalance) does not allow us to explore whether animals at all can have right etc., yet our concern

${ }^{14}$ Robinson, An Introduction to Early Greek Philosophy, 1968. should be how we could retrieve animals' right to them in a sophisticated manner. Tom Regan sounds more appealing, when he says:

...No one has a right to be protected against being harmed if protection in question involves violating the right of others... ${ }^{15}[12]$.

Here the existing question is how could the progress of medical science be possible without using the animals simply as their means for experiment in order to invent medicines for relieving human lives from different terrible ailments? This is truly a big challenge for our society to advocate their promise pertaining to the claim of not killing animals. Human moral understanding that constructs the ideas of justice, moral conscience etc., actually comes from their instinctive non-derivative cognition that non-human animals are unable to attain biologically. Rationality or the different methods of communication for animals are not a right issue here, actually the enigma of cognitive disability regarding moral conscience and the self-legislation lead the animals to be morally perilous. Hence, one can argue in favour of the Plato-Aristotelian trend that the conception of right bestrews the people who have moral conscience or who have the possibilities to ensure the subject of morality in a refined way. Animals don't have any moral state of mind, so they could never be the autonomy of the subject position of any moral claim. Besides, they never act morally. We need to be compassionate for their lives and we must have some earnest obligations for preserving their lives to sustain the equilibrium of nature. However we have to fairly construct a disparity between the terms like obligation and right.

One very intriguing observation that is later raised by Pollan in support of predation sounds elegant in this context as he urges, 'predation is not a matter of morality or politics'16 [13]. Here Pollan argues that the demand of animal liberalists against predation seems a kind of 'profound ignorance' on the working procedures of natural laws that have its own method. Imposing moral rights to animals is a kind of worst anthropomorphism. We should be careful and thankful to the fellow animals, but that does not mitigate the conclusion in favour of the moral rights of the non-conscience animals. All of us are indubitably governed by the laws of nature and these are somehow deserving that nature will avert us to provide full moral rights to animals. This approach can be a good

\footnotetext{
${ }^{15}$ Regan, The Case for Animal Rights, 1983. 346-347.

16Pollan, Omnivore's Dilemma, 2006. 322.
} 


\section{Philosophy International Journal}

challenge to Peter Singer's model of the principle of equal consideration ${ }^{17}$ of interests to animals [14].

Moreover, Peter Singer's interesting thesis (gustatory satisfaction 18 against animals' killing) seems quite unfeasible as food habits and expediency gustatory are not the precise justificatory ground, whereas Regan is more forceful when he focuses on the problem from a holistic utilitarian way [15]. Killing animals for preserving or retailing their meats are not only rest on the gustatory riddles but it is also a huge globalized commerce. This would be an exigent fact to expose how many people are intentionally and non-intentionally associated with this business. We cannot criticize only the butchers or the consumers for their animals killing. There may be some vegan scientists who invented a medicine to preserve meats for a long or meat packaging designers, or packaged meat shippers who perhaps unwillingly are compelled to being a part of their respective businesses because of their employment policies ${ }^{19}[16]$.

If we intend to bypass the debate and concentrate on the core area of moral rights of animals, then undoubtedly the pertinent point is what sorts of criterion an animal needs to accomplish for becoming a moral agent or moral patient. Regan's model edifices so many criterions like perception, belief, memory, desire, sense of future, psychological identities, emotion, pain, pleasure etc., which collectively makes an animal as a subject-of-a-life ${ }^{20}$. But the disagreement will interweave only if Regan strongly claims that the criterions should be solely followed by mammals rather than reptiles, fishes or birds etc. My point is that Wittgenstein's model of family resemblance can be a right way that always suggests us a weaker view to share most of the common features (not anyway all) as animals may have the criteria of psychological identities, but incapable to construct any future sense.

\footnotetext{
${ }^{17}$ Singer says, "The essence of the Principle of Equal Consideration of Interests is that we give equal weight in our moral deliberations to the like interests of all those affected by our actions", Singer, Practical Ethics, 1993. 21.

${ }^{18}$ Singer writes, "Since, as I have said, none of these practices (of raising animals intensively) caters for anything more than our pleasures of taste, our practice of rearing and killing other animals in order to eat them is a clear instance of the sacrifice of the most important interests of other beings in order to satisfy trivial interests of our own ... we must stop this practice, and each of us has a moral obligation to cease supporting this practice.", Singer, 'All animals are equal', 1989. 155.

${ }^{19}$ Rowlands, Animal Rights, Moral Theory and Practice, 2009. 54-56.

${ }^{20}$ Regan, The Case for Animal Rights, 1983. 243
}

Moral rights of animals sound as a valid claim, but there is no moral simplicitor that can detect the criterion to be a moral agent. Moral patients are another aspect, where we find some particular animals or non-beings who do not have most of the features to becoming an animal as depicted by Regan, although they may still have lives like reptiles, fishes etc. In addition, acceding Regan to an extent, all subject-of-a-life sufficiently (not necessarily) have inherent values. The most significant characteristic of inherent value concise its boundary within the frame line of incommensurability of intrinsic value of animals. Mark Rowlands clarifies:

If we suppose that subjects-of-a- life do possess inherent value, then we can explain our considered beliefs about the importance of justice and about what just treatment amounts to. So, the postulation of inherent value, at least on Regan's view, is an explanation of our considered moral beliefs - or as Rawls would put it, our reflective intuitions - concerning justice. And given the manifest, or at least arguable, failure of other theories to account for these beliefs or intuitions, we have good reason for supposing that the postulation of inherent value is the best explanation of these beliefs. Thus, inherent value is a theoretical postulate, justified, on Regan's view, as an inference to the best explanation ${ }^{21}$.

\section{Concluding Remarks}

A prima facie view that humanity aims to maintain is not to harm the subject-of-a-life, this principle has a remarkable relation to the revered principle that focuses on the valid claim of respect and to keep safe others lives.

The question of moral right of animals is emerged when according to Regan's look the two statues like $a$ valid claim-against and a valid claim-to can work together. Moral right bestows on a certain commodity which have a valid claim to all things painstaking to that commodity. Besides, a valid claim in defense of all things is considered against the particular policy work when individuals intend to provide the commodity and respect to the other animals. So an individual who possesses inherent value must have the moral right to deserve moral treatment from the society and others. But this policy goes towards an absurdity as it will contravene the food circle of the environment. If a cat chases a rat, then our duty would be to prevent the cat from marauding on rat for the sake of saving the life of the rat. In this case, we are doing injustice with the rat as our quest will coerce the cat to pass through starvation and this course of action leads the

21Rowlands, Animal Rights, Moral Theory and Practice, 2009. 65. 
particular cat to painful death. We nevertheless contravene the natural cum biological right of animals and their food habits. But if it confronts with human lives, then the picture becomes totally change. In normal cases when a tiger aims to prey a man for satisfying his hunger, it cannot be regarded as natural cum biological food habit of an animal. Here saving the life of a man is more significant than the dying of the tiger. This may be because a common human life is more paradigmatic than the life of any other animal. Humans have superior moral values that are highly unavailable in animal lives. These sorts of anti-speciesist arguments encircle in the domain of human existence and human facilities. It sounds true that our intended tests to separate men from animals always regain prolific, but the criterions that make the demarcation sometimes also may lack in human beings. These entire criterions like non-rationality, immorality, unconsciousness, non-language user etc may not be invoked even in the case of child, coma patient, etc although they are human being and have the potentiality to be human.

Human beings intend to make animals life easier and cheerful especially for those who are under controlled by us and who have some domestic senses. Our empathetic mind sometime treats them as our friend, guest or holy creatures who have direct lineage with deities. A type of anthropomorphism that is nourished by empathy escorts us to think and confer animals about their rights from a sympathetic outlook. We may consider it as a goodness of human nature. I undermine the anti-speciesist approach from this level. Animals' rights are beyond of any compassion or empathetic outlook of human beings. The right of animals is a kind of right they can fully claim without being anthropomorphic. It may be true that animals don't have the sense of justice, but being a living creature, the proclamation of justice to be alive is a natural right for them. Right cannot be considered as something that depends on others compassion and charity. Animal rights, I assume from the level of anthropomorphism makes it more reliable to quasi-right, i.e., a legal concept, in which some rights similar to those rights (in anthropomorphic sense) may be ensued by a group who perform an act which promotes societal benefits altogether. For the sake of promoting mankind and their secure existence, if we consider that we should care for the lives of animals and so and so by safeguarding brutal animals killing or by being more compassionate about saving animals lives, then the venture of right of animals (animals should have right policy) and animal welfare protection rules look contemptuous. Here the animal welfare protection indirectly hints at saving human existence. Animals are not the property of human being, about whom we can enforce laws to preserve them securely. Animals are the property of nature as humans are and their rights are enshrined by the natural laws, not in any way by human compassion or in a word animal rights are beyond of any human compassion. Human must not place themselves as the master of the world or as collective agents having control over the non-human groups. Man's own position in this world still remains insecure and they are still in the hands of nature's laws. The conception of autonomy and the idea of empathy to animal rights are a pipe dream. Besides, the conception of rights asks that it should not be delimited by other's ideals and generosity. I consider Korsgaard's opinion more appealing, when she claims:

They live according to their natures, not according to their values or their free choices or their personal conceptions of what is good. Nor is there much to be said for granting them to the nearest analogy to that kind of liberty - freedom of action in the simplest sense, allowing them to go where they please and do what they want ${ }^{22}$ [17].

One cannot sue that humans must have right to live and work as these are not any provisional rights of human beings; similarly, we should endue the animals a suitable situation for enjoying their own rights as our fellow creatures. Rights of animals are a kind of collective agency rights that pertain to all non-human animals in general instead of the domestic animals who enjoy more rights since they are appealing to humans; whereas the wilds seem more ferocious to humans, so we disrupt their rights. Rights are in general neutral and besides, Darwinian evolution theory emphasizes that animals are not in any way human properties or the subject of human's will, because animals strive for their own existence from the beginning of the world. It is true that we have no right to claim against animals as they are not moral conscience beings, in the same manner animals also have no right to claim against humans or to fellow animals as they (animals) do not have the freedom to think morally. But the point is that not to think morally does not express the consequence that the subject as living being is beyond any moral concern. Moral laws are relational and these are centre around the periphery of human beings. Therefore, by turning back to human's concern for moral laws edify the connection between humans and the specific animals. Preservation of human's autonomy is a good view that has been well supported by Darwinian model too, but one obsession we should follow

${ }^{22}$ Korsgaard, "Two Claims of Animals and the Needs of Strangers: Two Cases of Imperfect Rights" 7. 


\section{Philosophy International Journal}

that 'In fact, we ourselves make claims of individual claims of right, a commitment to dealing fairly with our fellow inhabitants ${ }^{23}$, a representation that tinges more close to Mrs. Thatcher's philanthropic adage 'one-of-usness'!

\section{References}

1. Plato (1921) Laws of Plato. Trans: England EB, Manchester: Manchester University Press.

2. Plato (2008) Timaeus and Critias. Trans: Waterfield R, Oxford: Oxford University Press.

3. Aristotle (2009) The Nicomachean Ethics. Trans: David Ross, New York: Oxford University Press.

4. Cicero (1928) On the Republic, On the Laws. Trans: Clinton W Keyes. Loeb Classical Library 213. Cambridge, MA: Harvard University Press.

5. Long AA (1986) Hellenistic Philosophy, Berkley, Los Angles: University of California Press.

6. Richard S (1993) Animals Mind and Humans Morals. London: Duckworth.

7. Aristotle (2010) Rhetoric. Trans: Rhys Roberts W, New York: Cosimo Classic.

8. Aristotle (1999) Politics. Trans: Benjamin Jowett, Kitchener, Batoche Book.
9. (1991) Theophrastus of Eresus. Trans: William Fortenbaugh, Pamela Huby, Robert Sharples, Dimitri Gutas, Leiden.

10. Porphyry (1823) Selected Works of Porphyry. Trans: Thomas Taylor, London: Thomas Rodd, 17 Great New Port Street.

11. Robinson, John Mansley (1968) An Introduction to Early Greek Philosophy. Boston: Houghton Mifflin Co.

12. Regan T (1983) The Case for Animal Rights. Berkeley: University of California Press.

13. Pollan (2006) Michael, Omnivore's Dilemma. New York: The Penguin Press.

14. Singer P (1993) Practical Ethics, Cambridge: Cambridge University Press.

15. Singer P (1989) 'All animals are equal', in Animal rights and Human Obligations. Tom Regan and Peter Singer (Eds.), New Jersey: Prentice-Hall.

16. Rowlands M (2009) Animal Rights, Moral Theory and Practice. London, New York: Palgrave Macmillan.

17. Korsgaard Christine (2018) Two Claims of Animals and the Needs of Strangers: Two Cases of Imperfect Rights.

${ }^{23}$ ibid., 36.

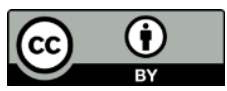

